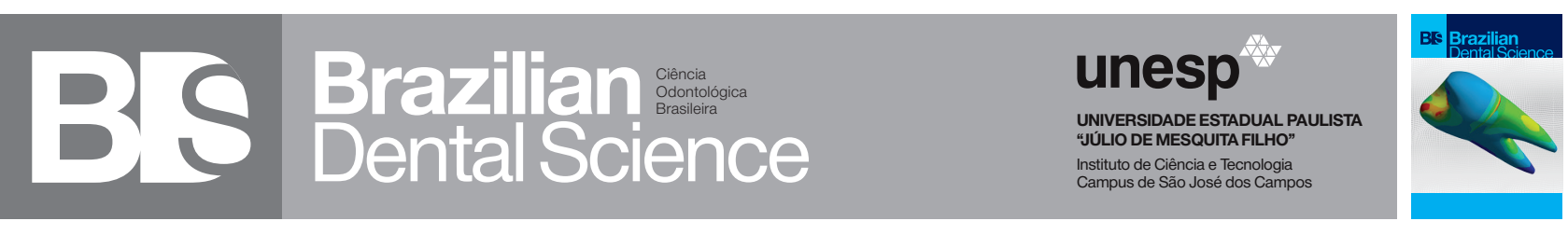

\title{
Marginal adaptation in proximal cavities restored with composites and other materials
}

\author{
Adaptação marginal em cavidades proximais com compósitos e outros materiais \\ Raphaela Farias RODRIGUES ${ }^{1,2,3}$, Suellen Scarcelli SENNA ${ }^{1}$, Ana Flávia SOARES ${ }^{1}$, Rafael Francisco Lia MONDELLI ${ }^{1}$, Paulo Afonso \\ Silveira FRANCISCONI ${ }^{1}$, Ana Flávia Sanches BORGES ${ }^{1}$ \\ 1 - Department of Dentistry, Endodontic and Dental Materials - Bauru School of Dentistry - Bauru - SP - Brazil. \\ 2 - Tiradentes University Center - AL - Brazil. \\ 3 - Health Science University of Alagoas - AL - Brazil.
}

\section{ABSTRACT}

Objective: To evaluate the marginal adaptation, in enamel (E) and dentin (D), of composite resin (CR) associated with flowable resin composite (flow), bulk fill flowable base (bulk) and resin modified glass ionomer cement (RMGIC) in slot cavities. Material and Methods: The study was conducted after approval (Protocol No. 21148413.4.0000.5417) from Ethics Committee. Forty extracted human molar teeth were randomly assigned in eight experimental groups: E-CR, E-BULK, E-FLOW, E-RMGIC, D-CR, D-BULK, D-FLOW, D-RMGIC. The occlusal surface was planned, two slot cavities with standard sizes (depth: $2.0 \mathrm{~mm}$, height: $2.5 \mathrm{~mm}$, width: $2.0 \mathrm{~mm}$ ) were created on a machine for making cavities. The teeth were restored and after $24 \mathrm{~h}$ subjected to 2000 cyclic loading and sectioned for analysis of marginal adaptation by scanning electron microscopy (SEM). The micrographs were analyzed with the Image J program to measure the size of marginal gaps. The data were transformed into percentages $(\%$ GAPS $=\mathrm{LG} \div \mathrm{LM} \times 100)$ and analyzed by 2 -way ANOVA followed by the post hoc Tukey test $(\alpha=0.05)$. Results: There was a significant difference between different treatments $(p<0.01)$. The groups E-RMGIC $(p=0.001)$ and D-RMGIC $(p=0)$ had the highest percentage of marginal gap. Others groups showed similar percentage of marginal gap $(p>0.05)$. Conclusions: It was concluded that restorations with flowable composite resin and bulk fill liners exhibit the same behavior, but the RMGIC liner increased marginal gap.

\section{KEYWORDS}

Composite resins. Dental marginal adaptation. Glass ionomer cements.

\section{RESUMO}

Objetivo: Avaliar a adaptação marginal, em esmalte (E) e dentina (D), de restaurações com resina composta (RC) associada a resina composta fluida (flow), resina bulk fill (bulk) e cimento de ionômero modificado por resina (CIVMR) em cavidades tipo slot. Materiais e Métodos: O estudo foi realizado após aprovação no Comitê de Ética e Pesquisa (Protocolo no. 21148413.4.0000.5417). Quarenta molares humanos foram aleatoriamente distribuídos em oito grupos experimentais: E-RC, E-BULK, E-FLOW, E-CIVMR, D-RC, D-BULK, D-FLOW, D-CIVMR. A superfície oclusal foi planificada e duas cavidades tipo slot com tamanhos padronizados (profundidade: 2,0 mm, altura: 2,5 $\mathrm{mm}$, largura: $2,0 \mathrm{~mm}$ ) foram realizadas em uma máquina para confecção de cavidades. Os dentes foram restaurados e, após $24 \mathrm{~h}$, submetidos a 2000 ciclos mecânicos e foram seccionados para análise da adaptação marginal em microscopia eletrônica de varredura (MEV). As micrografias foram analisadas através do programa Image $\mathrm{J}$ para medir as fendas marginais. Os dados foram transformados em porcentagens (\%fendas = largura da fenda / largura da margem x 100) e analisados através do teste ANOVA-2 critérios seguido do teste de Tukey $(\alpha=0,05)$. Resultados: Houve diferença significante entre os diferentes tratamentos $(p<0,01)$. Os grupos E-CIVMR $(p=0,001)$ D-CIVMR $(p=0)$ apresentaram a maior porcentagem de fenda marginal. Os outros grupos mostraram porcentagem similar de fenda marginal $(p>0,05)$. Conclusões: Concluiu-se que as restaurações com base de resina flow e bulk fill exibiram o mesmo comportamento, mas a base de CIVMR aumentou a fenda marginal.

\section{PALAVRAS-CHAVE}

Resinas compostas; Adaptação marginal dentária; Cimentos de ionômeros de vidro. 


\section{INTRODUCTION}

S hrinkage stress is the fundamental reason why composite polymerization shrinkage is a clinical concern [1-4]. Polymerization contraction, which induces stress when the shrinkage cannot be accommodated by viscous flow of the composite [5], is capable of causing initial gaps in the restorations margins [6], leading to tooth sensitivity, pulp damage [7], and secondary caries [8,9]. This situation becomes more critical in class II restorations due to the difficulty of adapting the material at the gingival margin [10-12].

Viscous materials exhibit low wetting capacity that interferes in adaptation of the material in the cavity, therefore, flowable materials may be a good alternative to improving marginal integrity and internal adaptation of restorations [13]. Since flowable composite liners or glass ionomer liners act as a more resilient elastic layer, absorbing more energy from the shrinkage stress, they also act as a buffer causing better marginal fit, because their low elastic modulus promotes higher elastic deformation to compensate the shrinkage stress [14-16].

Thus, the objective of the study was to evaluate the marginal adaptation, in enamel (E) and dentin (D), of adhesive materials, such as composite resin (CR), flowable resin composite (flow), bulk fill flowable liner (bulk) and resin modified glass ionomer cement (RMGIC) in slot cavities. The hypothesis tested was that different materials did not influence the marginal adaptation in enamel and dentin.

\section{MATERIALS AND METHODS}

This study was conducted after approval (Protocol No. 21148413.4.0000.5417) from Ethics Committee of the Bauru School of Dentistry. In total, 40 extracted human molar teeth without caries were used. The teeth were embedded in PVC tubes (diameter: $15 \mathrm{~mm}$, height: $25 \mathrm{~mm}$ ) with acrylic resin, leaving the cemento-enamel junction (CEJ) exposed. The occlusal surface was planed in a water-cooled mechanical grinder and polisher (ER-27000;

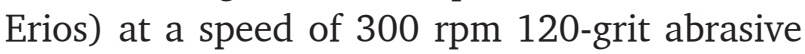
paper was used for three minutes, teeth were shaped with vinyl polysiloxane prior to cavity preparation, and the mold was used as matrix for cavity restorations (Figure 1).

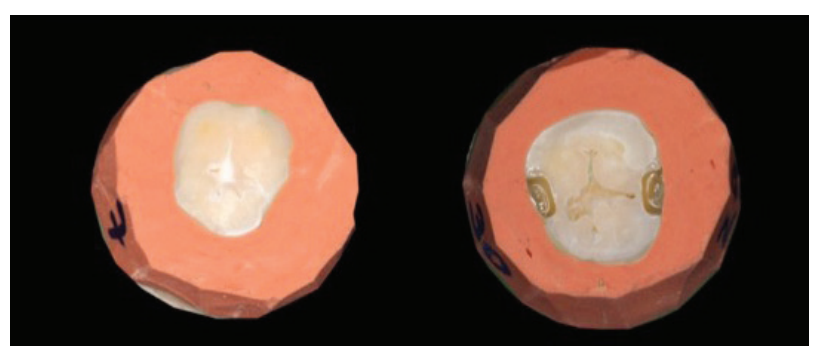

Figure 1 - Vinyl polysiloxane matrix.

The forty teeth were randomly assigned into eight experimental groups (5 teeth per group) according to Table 1 . For each tooth, two vertical slot preparations with standard sizes (depth: $2.0 \mathrm{~mm}$, height: $2.5 \mathrm{~mm}$, width: $2.0 \mathrm{~mm}$ ) were created, in mesial and distal of the same tooth, with burs \#245 (KG Sorensen, São Paulo, SP, Brazil) on a machine for making cavities (ELQUIP, São Carlos, SP, Brazil). This device has three digital micrometers coupled to the table, a coordinate system supporting a high-speed turbine that determines the depth of wear and the inclination of the rotating device. The burs were replaced after five preparations.

Cervical margins were defined in enamel and dentin in relation to CEJ. Thus, for the cervical margins in enamel the preparation was carried out short of CEJ and for dentin, besides CEJ. Considering that for each tooth two cavities are made, forty cavities were made with enamel margin and forty cavities with margin in dentin.

The restorations were made with Filtek Z350 composite resin (3M Espe, St. Paul, MN, USA) by the incremental technique, with or without liner: by using flowable resin Filtek Z350 (3M ESPE, St. Paul, MN, USA) and 
Surefil SDR (Dentsply, Konstanz, Germany) and RMGIC Vitremer (3M Espe, St. Paul, MN, USA). Flowable and bulk resin composites, and RMGIC were placed in a single increment $(2.0 \mathrm{~mm})$ by "open sandwich" technique. Polymerization was performed with a DB 686 LED appliance (Dabi Atlante, Ribeirão Preto, SP,
Brazil). The adhesive treatment of substrates was performed according to the manufacturers' recommendations, and the excess material was removed with a scalpel blade. The materials, batch numbers, and manufacturers are listed in Table 2.

Table 1 - Experimental groups

\begin{tabular}{ccc}
\hline $\begin{array}{c}\text { Groups } \\
(\mathbf{n}=\mathbf{1 0} \text { restorations })\end{array}$ & Cervical margin & Adhesive Material \\
\hline E-CR & Enamel & Filtek Z350 composite resin \\
\hline E-BULK & Enamel & Filtek Z350 composite resin + SDR flowable composite $(2 \mathrm{~mm})$ \\
\hline E-FLOW & Enamel & Filtek Z350 composite resin + Filtek Z350 flowable composite $(2 \mathrm{~mm})$ \\
\hline E-RMGIC & Enamel & Filtek Z350 composite resin + RMGIC Vitremer (2mm) \\
\hline D-CR & Dentin & Filtek Z350 composite resin \\
\hline D-BULK & Dentin & Filtek Z350 composite resin + SDR flowable composite $(2 \mathrm{~mm})$ \\
\hline D-FLOW & Dentin & Filtek Z350 composite resin + Filtek Z350 flowable composite $(2 \mathrm{~mm})$ \\
\hline D-RMGIC & Dentin & Filtek Z350 composite resin + RMGIC Vitremer $(2 \mathrm{~mm})$ \\
\hline
\end{tabular}

Table 2 - Batch number and manufacturer of materials used in this study

\begin{tabular}{|c|c|c|}
\hline Material & Batch & Manufacturer \\
\hline Phosporic Acid - Phosphoric acid 37\%, colloidal silica, surfactant, and colorant & 140213 & Dentsply, Konstanz, Germany \\
\hline Adper Scotchbond Primer - 2-hydroxyethyl-methacrylate and polyalkenoic acid & N481327 & 3M ESPE, St. Paul, MN, USA \\
\hline $\begin{array}{l}\text { Adper Scotchbond Adhesive - Bismethacrylate (1-methylethylidene) bis (4,1-phenylenoxy } \\
\text { [2-hydroxy-3,1-propanediyl]) and 2-hydroxyethyl methacrylate }\end{array}$ & N465871 & 3M ESPE, St. Paul, MN, USA \\
\hline $\begin{array}{l}\text { Filtek Z350 composite resin - Ceramics treated with silane, BIS-GMA, BIS-EMA, silica and } \\
\text { zirconia treated silane, dimethacrylate diurethane, polyethylene glycol dimethacrylate, } \\
\text { TEG-DMA, 2,6-di-tert-butyl-p-cresol (BHT) }\end{array}$ & 726707 & 3M ESPE, St. Paul, MN, USA \\
\hline $\begin{array}{c}\text { Filtek Z350 flowable - Ceramics treated with silane, substituted dimethacrylate, bisphe- } \\
\text { nol A diglycidyl ether dimethacrylate (BIS-GMA), silane treated silica, triethylene glycol } \\
\text { dimethacrylate (TEG-DMA), ytterbium fluoride, functionalized dimethacrylate polymer and } \\
\text { titanium dioxide. }\end{array}$ & N470064 & 3M ESPE, St. Paul, MN, USA \\
\hline $\begin{array}{l}\text { SureFil SDR flowable (Bulkfill) } \\
\text { Modified UDMA, TEGDMA, EBPDMA, pigment, photoinitiator, barium and strontium alumi- } \\
\text { no-fluoro-silicate glasses, Silicon Dioxide-Amorphous, Strontium. Aluminosilicate Glass. } \\
\text { Filler load: } 68 \text { wt\%; } 45 \text { vol\%. }\end{array}$ & 02221 & Dentsply, Konstanz, Germany \\
\hline Vitremer - Powder: silane treated glass, potassium persulfate, pigments. & N449108 & \\
\hline $\begin{array}{l}\text { Liquid: copolymer of acrylic and itaconic acids, water, 2-hydroxyethyl methacrylate } \\
\text { (HEMA), diphenyliodonium hexafluorophosphate }\end{array}$ & N394817 & 3M ESPE, St. Paul, MN, USA \\
\hline $\begin{array}{c}\text { Primer: 2-hydroxyethyl methacrylate (HEMA), ethyl alcohol, copolymer of itaconic and } \\
\text { acrylic acids, diphenyliodonium hexafluorophosphate }\end{array}$ & N509198 & \\
\hline
\end{tabular}


Subsequently, the specimens were stored in deionized water for $24 \mathrm{~h}$. After this they were subjected to 2000 cyclic loading, $120 \mathrm{~N}, 2 \mathrm{~Hz}$ (Elquip, São Carlos, SP, Brazil) at $37^{\circ} \mathrm{C}$, and then sectioned sagittal direction in relation to the tooth`s long axis by a cutting machine (Isomet low speed saw - Buehler, Lake Bluff, IL, USA) to analyze the marginal adaptation of the restored cavities. This analysis was performed by scanning electron microscopy (SEM) at 35x magnification (JSM-T220A, Jeol, Tokyo, Japan) that allowed full view of the cervical margin. The micrographs were analyzed with the Image $\mathrm{J}$ program to measure the size of the marginal gaps. This program provides the corresponding marginal extension of the microgap by converting pixels into square millimeters. The distance between the margins of restorations was used to calibrate the program.

The data were transformed into percentages using the formula $\%$ GAPS $=\mathrm{LG} \div \mathrm{LM} \times 100$, where LG is the length of the gap and LM is the total length of the margin. Gap percentage values of restorative treatments, in enamel and dentin, were analyzed by 2-way ANOVA followed by the post hoc Tukey test $(\alpha=0.05)$.

\section{RESULTS}

The percentages of marginal gap in each group are shown in Figure 2. The results of the 2 -way ANOVA of marginal gap data are listed in Table 3.

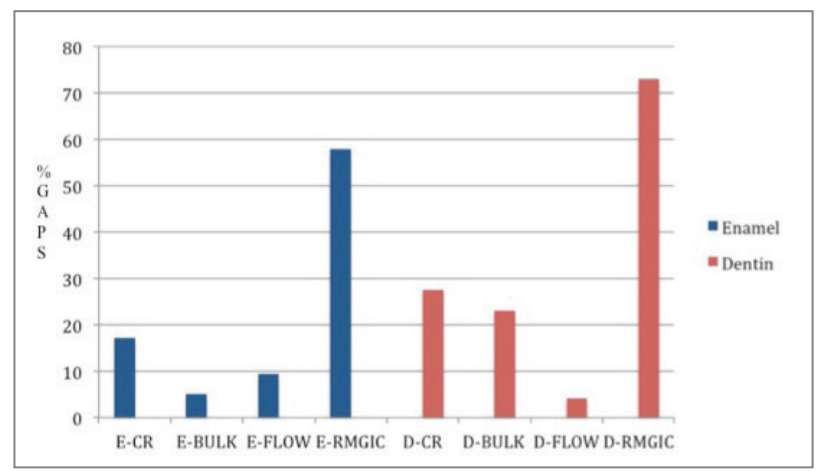

Figure 2 - Percentages of marginal gaps in the tested groups.
Table 3 - Two-way ANOVA $(P<0.05)$

\begin{tabular}{|cccccc|}
$\begin{array}{c}\text { Source of } \\
\text { Variation }\end{array}$ & df & $\begin{array}{c}\text { Sum of } \\
\text { Squares }\end{array}$ & $\begin{array}{c}\text { Mean } \\
\text { Squares }\end{array}$ & F & P \\
\hline T & 3 & $41,380.60$ & $13,793.53$ & 21.58419 & 0.0000 \\
\hline S & 1 & $1,796.59$ & $1,796.59$ & 2.81131 & 0.0979 \\
\hline TxS & 3 & $1,603.87$ & 534.62 & 0.83658 & 0.4781 \\
\hline
\end{tabular}

T, treatments; S, substrate.

There was a significant difference between different experimental treatments in relation E-RMGIC and D-RMGIC and others groups $(p<0.01)$ (Table 4$)$. The combination of composite resin with modified glass ionomer resin by using the open sandwich technique had the highest percentage of marginal gap in enamel (E-RMGIC: $57.91 \pm 35.56 \%$ ) and dentin (D-RMGIC: $72.98 \pm 29.05 \%$ ). There was not difference between enamel and dentin $(\mathrm{p}=0.0979)$.

Table 4 - Experimental groups and standard deviation (SD)

\begin{tabular}{|cc|}
\hline Groups & Median(SD) \\
\hline E-CR & $17,22(33,77) \mathrm{a}$ \\
\hline E-BULK & $5.15(13.62) \mathrm{a}$ \\
\hline E-FLOW & $9.59(17.08) \mathrm{a}$ \\
\hline E-RMGIC & $57.91(35.56) \mathrm{b}$ \\
\hline D-CR & $27.53(26.22) \mathrm{a}$ \\
\hline D-BULK & $23.00(25.05) \mathrm{a}$ \\
\hline D-FLOW & $4.28(8.43) \mathrm{a}$ \\
\hline D-RMGIC & $72.98(29.05) \mathrm{b}$ \\
\hline
\end{tabular}

The groups restored with composite resin (E-CR: $17.22 \pm 33.77 \%$, D-CR: $27.53 \pm$ $26.22 \%$ ) and with flowable composite resin liner (E-BULK: $5.15 \pm$ 13.62\%, E-FLOW: 9.59 \pm 17.08\%, D-BULK: $23 \pm 25.05 \%$, D-FLOW: $4.28 \pm 8.43 \%$ ) showed a similar percentage of marginal gap $(\mathrm{p}>0.05)$. Photomicrographs are shown in Figure 3. 


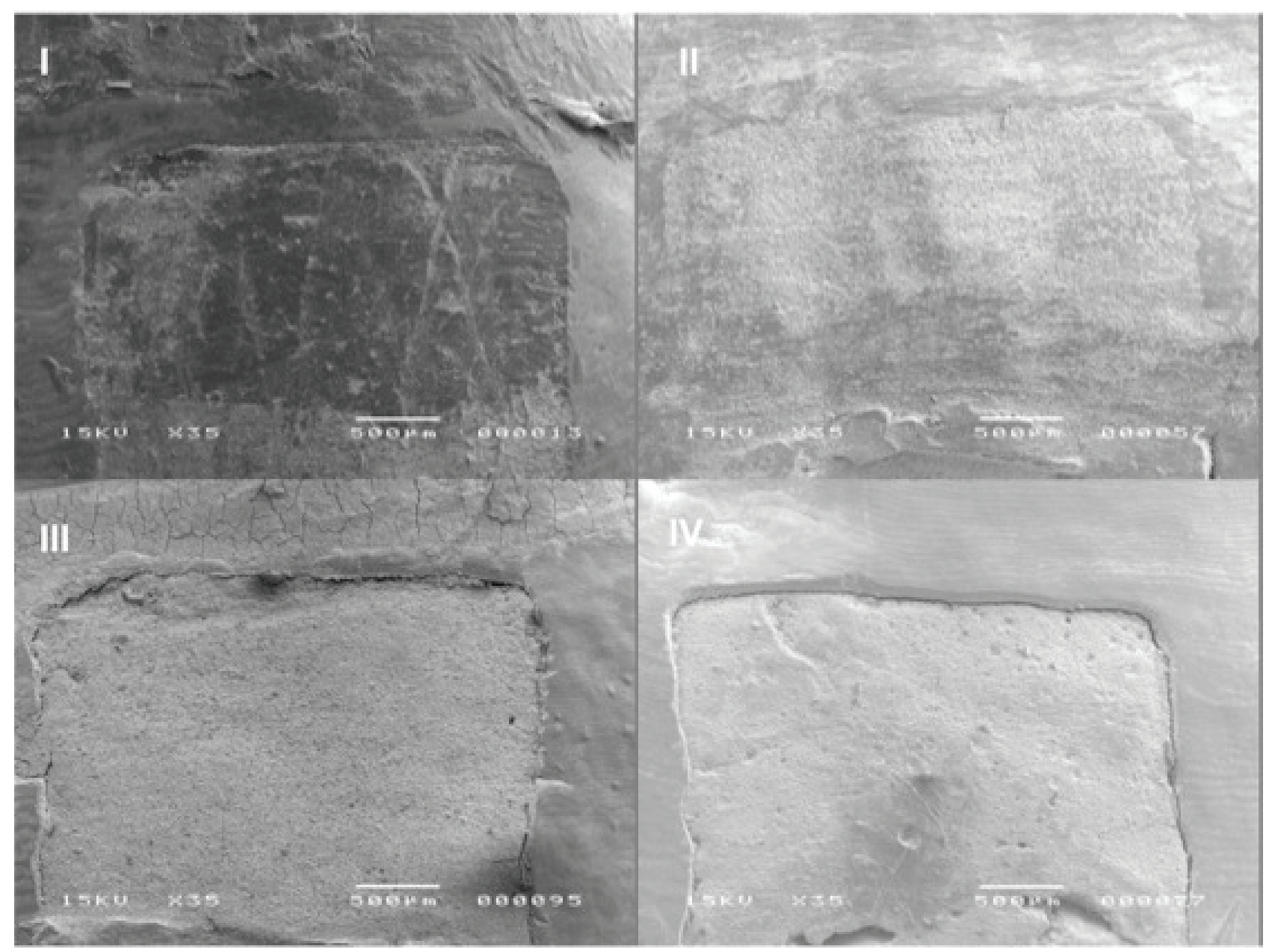

Figure 3 - Scanning electron microscope image (x35 magnification) of specimens. I and II, absence of marginal gap; III and IV, presence of marginal gap.

\section{DISCUSSION}

Gaps can compromise the restoration due to infiltration of fluids and bacteria that can lead to the development of secondary caries $[8,9]$. This study investigated the percentage marginal gap by means of SEM analysis of different treatments with composite resin, and flowable, bulkfill, and RMGIC by open sandwich technique in enamel and dentin cervical margins. The hypothesis tested was rejected because different materials influenced the marginal adaptation in enamel and dentin.

Two flowable resin composites were tested: Filtek Z350 Flow (3M ESPE, St. Paul, MN, USA) and Surefil SDR Flow - bulk fill flowable base - (Dentsply, Dentsply, Konstanz, Germany).

The flowable composite Filtek Z350 has $65 \%$ of filler particles by weight that reduces its stiffness; and it must be used in up to $2 \mathrm{~mm}$ increments. Among the components of the composition, UDMA and Bis-EMA are resins with higher molecular weight that have fewer double bonds resulting in less shrinkage, and PEGDMA, in moderating shrinkage. The Surefil SDR Flow has $68 \%$ filler by weight; has fluoride in its formulation and offers the possibility of up to $4 \mathrm{~mm}$ increments since it presents a differential urethane dimethacrylate monomer associated with a modulator of polymerization 
that results in a low polymerization shrinkage stress.

It was observed that the combination of these flowable resins $(2 \mathrm{~mm})$ with composite resin did not influence the marginal adaptation after 2000 mechanical loading cycles, of cavities filled with the hydrophobic 3-step adhesive system Adper Scotchbond Multipurpose (3M ESPE, St. Paul, MN, USA). Scotchbond primer consists of an aqueous solution of 2-HEMA and a copolymer of polyalkenoic acid that increases the resistance of the adhesive system when used in the oral environment with a high level of humidity. Pecie et al. [17] also observed no improvement in marginal adaptation, before and after the thermal cycling, when they used a flowable resin liner and a 3-step adhesive system Optbond FL (Kerr Corporation). Several authors have demonstrated the superiority of conventional adhesives in maintaining marginal integrity at the dentin/resin interface [18,19]. Aggarwal et al. (2014) [8] observed improvement when they used a flowable liner and 2-step resin adhesive system, but when the 1-step self-adhesive system was used, the flowable resin liner did not influence the marginal adaptation in comparison with the composite resin used alone.

Flowable resins are heterogeneous materials, since they have different modulus of elasticity and shrinkage [20,21]. The performance of these resins is unpredictable with respect to the absorption of stress at the interface [17]. Thus, they should be used with caution, avoiding thick layers, since the low filler content may contribute to the increased polymerization shrinkage [8]. Some studies have found conflicting results with regard to the effect of flowable resin liner on marginal integrity $[10,22,23]$.

Another type of liner used in this study was the RMGIC Vitremer (3M ESPE, St. Paul, MN, USA). The primer of Vitremer, which was used previously to applying the RMGIC, is a tooth structure conditioner composed of copolymer modified polyalkenoic acid, methacrylate groups, ethanol and camphoroquinone, and its function is to moisten the tooth surface to increase the bond of RMGIC.

When the RMGIC was used, the percentage of marginal gap increased in enamel and dentin. On the one hand, the RMGIC has an anticariogenic effect due to fluoride release [24] and chemically bonds to dental substrate through bonding of the carboxylic groups of polyalkenoic acid to hydroxyapatite [25]; on the other, RMGIC has technique sensitivity from manipulation though to final setting, and a very viscous consistency that makes it difficult to insert and accommodate in the cavity [26], so that it use requires a well-trained and experience operator. Furthermore, when RMGIC is exposed to the oral environment, its surface may deteriorate due to its solubility $[27,28]$.

The literature reports studies that had failures with the use of GIC in the "open sandwich" technique [26,29-31]. Whereas, many authors have observed that the GIC improved marginal integrity [8,15,26,32]. Other authors have suggested dentin hybridization with an adhesive system before RMGIC application to guarantee dentinal tubule sealing in case of failure at the interface [33]. In the present study, RMGIC was used without an adhesive system, in accordance with the manufacturer's indications for the material used.

Although many materials are being developed to facilitate the implementation of clinical procedures, the main factor that seems to influence the possibility of success is the ability and technical expertise of the operator.

\section{CONCLUSION}

It was concluded that the different restorative treatments had the same behavior in enamel and dentin cervical margins. Restorations with flowable composite resin liner and bulk fill 
did not influence marginal adaptation, however the association RMGIC with composite resin increased the percentage of marginal gap in the slot cavities.

\section{REFERENCES}

1. Bouschlicher MR, Vargas MA, Boyer DB. Effect of composite type, light intensity, configuration factor and laser polymerization on polymerization contraction forces. Am J Dent. 1997 Apr;10(2):8896.

2. Kemp-Scholte CM, Davidson CL. Marginal integrity related to bond strength and strain capacity of composite resin restorative systems. J Prosthet Dent. 1990 Dec;64(6):658-64.

3. Sakaguchi RL, Sasik CT, Bunczak MA, Douglas WH. Strain gauge method for measuring polymerization contraction of composite restoratives. J Dent. 1991 0ct;19(5):312-6.

4. Versluis A, Tantbirojn D. Theoretical considerations of contraction stress. Compend Contin Educ Dent Suppl. 1999;(25):S24-32; quiz S73.

5. Suh BI, Feng L, Wang Y, Cripe C, Cincione F, de Rjik W. The effect of the pulse-delay cure technique on residual strain in composites. Compend Contin Educ Dent. 1999 Feb;20(2 Suppl):4-12; quiz 13-4.

6. Pallesen U, Qvist V. Composite resin fillings and inlays. An 11-year evaluation. Clin Oral Investig. 2003 Jun;7(2):71-9.

7. Rodrigues Junior SA, Pin LF, Machado G, Della Bona A, Demarco FF. Influence of different restorative techniques on marginal seal of class II composite restorations. J Appl Oral Sci. 2010 JanFeb;18(1):37-43.

8. Aggarwal V, Singla M, Yadav S, Yadav H. Effect of flowable composite liner and glass ionomer liner on class II gingival marginal adaptation of direct composite restorations with different bonding strategies. J Dent. 2014 May;42(5):619-25.

9. Manhart J, Chen H, Hamm G, Hickel R. Buonocore Memorial Lecture. Review of the clinical survival of direct and indirect restorations in posterior teeth of the permanent dentition. Oper Dent. 2004 Sep-0ct;29(5):481-508.

10. Korkmaz Y, Ozel E, Attar N. Effect of flowable composite lining on microleakage and internal voids in Class II composite restorations. J Adhes Dent. 2007 Apr;9(2):189-94.

11. Leevailoj C, Cochran MA, Matis BA, Moore BK, Platt JA. Microleakage of posterior packable resin composites with and without flowable liners. Oper Dent. 2001 May-Jun;26(3):302-7.

12. Tredwin CJ, Stokes A, Moles DR. Influence of flowable liner and margin location on microleakage of conventional and packable class II resin composites. Oper Dent. 2005 Jan-Feb;30(1):32-8.

13. Li Q, Jepsen S, Albers HK, Eberhard J. Flowable materials as an intermediate layer could improve the marginal and internal adaptation of composite restorations in Class-V-cavities. Dent Mater. 2006 Mar;22(3):250-7.

14. Karaman E, Ozgunaltay G. Polymerization shrinkage of different types of composite resins and microleakage with and without liner in class II cavities. Oper Dent. 2014 May-Jun;39(3):325-31.

15. Kasraei S, Azarsina M, Majidi S. In vitro comparison of microleakage of posterior resin composites with and without liner using two-step etch-and-rinse and self-etch dentin adhesive systems. Oper Dent. 2011 Mar-Apr;36(2):213-21.

16. Ozgunaltay G, Gorucu J. Fracture resistance of class II packable composite restorations with and without flowable liners. Journal of oral rehabilitation. 2005 Feb;32(2):111-5.

17. Pecie R, Onisor I, Krejci I, Bortolotto T. Marginal adaptation of direct class II composite restorations with different cavity liners. Oper Dent. 2013 Nov-Dec;38(6):E210-20.

18. Carvalho RM, Chersoni S, Frankenberger R, Pashley DH, Prati C, Tay FR. A challenge to the conventional wisdom that simultaneous etching and resin infiltration always occurs in self-etch adhesives. Biomaterials. 2005 Mar;26(9):1035-42.

19. Van Landuyt KL, Snauwaert J, De Munck J, Peumans M, Yoshida Y, Poitevin A, et al. Systematic review of the chemical composition of contemporary dental adhesives. Biomaterials. 2007 Sep;28(26):3757-85.

20. Labella R, Lambrechts P, Van Meerbeek B, Vanherle G. Polymerization shrinkage and elasticity of flowable composites and filled adhesives. Dent Mater. 1999 Mar;15(2):128-37.

21. Marchesi G, Breschi L, Antoniolli F, Di Lenarda R, Ferracane J, Cadenaro M. Contraction stress of low-shrinkage composite materials assessed with different testing systems. Dent Mater. 2010 0ct;26(10):947-53.

22. Cara RR, Fleming GJ, Palin WM, Walmsley AD, Burke FJ. Cuspal deflection and microleakage in premolar teeth restored with resinbased composites with and without an intermediary flowable layer. J Dent. 2007 Jun;35(6):482-9.

23. Oliveira LC, Duarte S Jr, Araujo CA, Abrahao A. Effect of low-elastic modulus liner and base as stress-absorbing layer in composite resin restorations. Dent Mater. 2010 Mar;26(3):e159-69.

24. Forsten $L$. Fluoride release and uptake by glass ionomers. Scandinavian journal of dental research. 1991 Jun;99(3):241-5.

25. Akinmade A0, Nicholson JW. Glass-ionomer cements as adhesives. Part I. Fundamental aspects and their clinical relevance. J Mater Sci Mater Med. 1993;4(2):93-101.

26. Czarnecka B, Kruszelnicki A, Kao A, Strykowska M, Nicholson JW. Adhesion of resin-modified glass-ionomer cements may affect the integrity of tooth structure in the open sandwich technique. Dent Mater. 2014 Dec;30(12):e301-5.

27. Holtan JR, Nystrom GP, Douglas WH, Phelps RA, 2nd. Microleakage and marginal placement of a glass-ionomer liner. Quintessence Int. 1990 Feb;21(2):117-22

28. Wibono G, stocktan LW. Microleakage of class II composite restorations. Am J Dent. 2001;14(3):177-85.

29. Andersson-Wenckert IE, van Dijken JW, Kieri C. Durability of extensive Class II open-sandwich restorations with a resinmodified glass ionomer cement after 6 years. Am J Dent. 2004 Feb;17(1):43-50.

30. van Dijken JW. A 6-year evaluation of a direct composite resin inlay/onlay system and glass ionomer cement-composite resin sandwich restorations. Acta Odontol Scand. 1994 Dec;52(6):36876 .

31. Welbury RR, Murray JJ. A clinical trial of the glass-ionomer cement-composite resin "sandwich" technique in Class II cavities in permanent premolar and molar teeth. Quintessence Int. 1990 Jun;21(6):507-12. 
32. Sampaio PC, de Almeida Junior AA, Francisconi LF, CasasApayco LC, Pereira JC, Wang L, et al. Effect of conventional and resin-modified glass-ionomer liner on dentin adhesive interface of Class I cavity walls after thermocycling. Oper Dent. 2011 JulAug;36(4):403-12.
33. Fritz UB, Finger WJ, Uno S. Marginal adaptation of resin-bonded light-cured glass ionomers in dentin cavities. Am J Dent. 1996 Dec;9(6):253-8.

Ana Flávia Sanches Borges

(Corresponding address)

Al. Octávio Pinheiro Brisola, 9-75,

Bauru, São Paulo, Brasil

Date submitted: 2017 Jun 04

CEP: 17012-901 